\title{
KEWENANGAN PENGADILAN AGAMA DAN PENGADILAN TATA USAHA NEGARA TERHADAP PEMBEBANAN NAFKAH ANAK AKIBAT PERCERAIAN PEGAWAI NEGERI SIPIL
}

\section{AUTHORITY OF RELIGIOUS COURT AND ADMINISTRATIVE COURT ON THE IMPOSITION OF LIVING COST FOR CHILDREN TO CIVIL SERVICE DIVORCE}

\author{
Khairil Fadri $^{1}$, Mukhlis ${ }^{2}$ dan Yusrizal ${ }^{3}$ \\ ${ }^{1}$ Pengacara di Lhokseumawe, Aceh \\ ${ }^{2,3}$ Program Magister Hukum, Universitas Malikussaleh, Aceh \\ Email: khairilfadribasri@gmail.com
}

\begin{abstract}
Religious Court is one of the judicial parties under the Supreme Court which is receiving, investigating and adjudicating divorce claim. One of the legal consequences of divorce cases is the imposition of living cost for children its results of marriage. This research is based on Jurisprudence Number 11K/AG/2001 dated July 10, 2003 which said the granting 1/2 the portion of Defendant's salary to the Plaintiff as stipulated in the Discipline Regulation of Civil Servants (PNS) is not a procedural law for the Religious Courts, but a Decree of the State Administration Officer. The problems in this thesis are: 1) the legal force of the religious court against the imposition of child's living cost from divorced civil servant parents, and 2) the execution of the authority of the state administrative court in deciding the case of child's living cost caused by divorce of a PNS. Method of the research employed normative juridical research. The data was analyzed by descriptive analysis techniques and content analysis. From the research, the researcher found the answer to the problems as follows: 1) Basically the burden of subsistence on divorced PNS parents is the authority of the religious courts, and 2) Administrative courts do not have the authority over that matter its causes the decision of administrative court about imposition of child's living cost can't be execute. Administrative Courts also do not have the authority to ratify the decisions of religious courts related to the imposition of child's living cost.

Keywords: Court's decision, divorce, the imposition of child's living cost, civil servants

\section{Intisari}

Pengadilan Agama adalah salah satu badan peradilan yang berada di bawah Mahkamah Agung yang kewenangannya menerima, memeriksa dan mengadili
\end{abstract}

Suloh Jurnal Program Studi Magister Hukum, Vol. 8, No. 1, April 2020, pp. 48 - 69 
perkara perceraian. Salah satu akibat hukum dari perkara perceraian adalah pembebanan nafkah untuk anak dari hasil perkawinan. Penelitian ini berdasarkan pada Yurisprudensi Nomor 11K/AG/2001 tanggal 10 Juli 2003 yang menyatakan bahwa pemberian $1 / 2$ bagian dari gaji Tergugat kepada Penggugat sebagaimana tertuang dalam Peraturan Disiplin Pegawai Negeri Sipil (PNS) bukan merupakan hukum acara Peradilan Agama, melainkan Keputusan Pejabat Tata Usaha Negara. Rumusan masalah yang timbul adalah 1) kekuatan hukum pengadilan agama terhadap pembebanan nafkah anak dari orangtua PNS yang bercerai dan 2) pelaksanaan kewenangan pengadilan tata usaha negara dalam memutus perkara pembebanan nafkah anak akibat perceraian seorang PNS. Penelitian ini menggunakan metode penelitian hukum normatif. Data yang didapat dari penelitian kepustakaan.

Kata Kunci: Putusan pengadilan, perceraian, pembebanan nafkah anak, pegawai negeri sipil

\section{- Pendahuluan}

Dalam Undang-Undang Dasar 1945 Perubahan ketiga, pasal 24 ayat (2) dikatakan bahwa kekuasaan kehakiman dilakukan oleh sebuah Mahkamah Agung dan badan peradilan yang berada di bawahnya dalam lingkungan peradilan umum, lingkungan peradilan agama, lingkungan peradilan militer, lingkungan peradilan tata usaha Negara, dan oleh sebuah Mahkamah Konstitusi. Keberadaan badan-badan peradilan ini kemudian dikuatkan dengan Undang-Undang Pokok Kekuasaan Kehakiman Nomor 14 Tahun 1970.

Kewenangan peradilan agama adalah bertugas dan berwenang memeriksa, memutus, dan menyelesaikan perkara di tingkat pertama antara orang-orang yang beragama Islam di bidang perkawinan, waris, wasiat, hibah, wakaf, zakat, infaq, shadaqah dan ekonomi syari'ah. Kewenangan peradilan tata usaha Negara adalah memeriksa dan memutus sengketa tata usaha Negara. Sengketa Tata Usaha Negara adalah sengketa yang timbul dalam bidang Tata Usaha Negara antara orang atau badan hukum perdata dengan Badan atau Pejabat Tata Usaha Negara, baik di pusat maupun di daerah, sebagai akibat dikeluarkannya Keputusan Tata Usaha Negara, termasuk sengketa kepegawaian berdasarkan peraturan perundang-undangan yang berlaku.

Dalam tulisan ini, masalah yang paling mendasar adalah terkait kewenangan dua badan peradilan yaitu peradilan agama dan peradilan tata usaha Negara karena terbitnya Yurisprudensi yang menyatakan seolah-olah bahwa pelaksanaan putusan pembebanan nafkah ayah yang PNS terhadap anaknya setelah diputus peradilan

Suloh Jurnal Program Studi Magister Hukum, Vol. 8, No. 1, April 2020, pp. 49 - 69 
agama harus dilakukan oleh peradilan tata usaha Negara. Oleh karena itu, menjadi penting untuk merinci masalah teori kewenangan dan kewenangan yang melekat pada kedua peradilan tersebut.

Indonesia sebagai negara hukum telah mengatur masalah perceraian dalam Undang-Undang Nomor 1 Tahun 1974 tentang Perkawinan (selanjutnya disebut UUP), Peraturan Pemerintah Nomor 9 Tahun 1975 tentang Pelaksanaan UndangUndang Nomor 1 Tahun 1974 tentang Perkawinan, Undang-Undang Nomor 7 Tahun 1989 tentang Peradilan Agama sebagaimana telah diubah dengan Undang-Undang Nomor 3 Tahun 2006 dan Undang-Undang Nomor 50 Tahun 2009, serta Kompilasi Hukum Islam.

Proses perceraian antara orang-orang yang beragama Islam menjadi kewenangan Pengadilan Agama sebagaimana diatur dalam Pasal 49 Undang-Undang Peradilan Agama. Sebagai lembaga peradilan yang berdasarkan hukum Islam, Peradilan Agama disebut peradilan khusus. Disebut demikian karena Peradilan Agama mengadili perkara-perkara yang ditentukan khusus oleh peraturan perundangundangan. ${ }^{1}$ Kekhususan itu pula berkenaan dengan perkara perceraian bagi para pihak yang berprofesi sebagai Pegawai Negeri Sipil (selanjutnya disebut PNS) dengan berlakunya aturan tambahan dalam Peraturan Pemerintah Nomor 10 Tahun 1983 tentang Izin Perkawinan dan Perceraian Bagi Pegawai Negeri Sipil, Peraturan Pemerintah Nomor 45 Tahun 1990 tentang Perubahan atas Peraturan Pemerintah Nomor 10 Tahun 1983 tentang Izin Perkawinan dan Perceraian Bagi Pegawai Negeri Sipil.

Aturan-aturan tersebut juga mengkhususkan akibat cerai seperti nafkah untuk anak dari hasil perkawinan orangtuanya yang berprofesi sebagai PNS. Dalam aturan tersebut Pasal 8 dikatakan bahwa mantan suami wajib menyerahkan sebagian gajinya untuk menghidupi bekas istri dan anak-anaknya. Besarnya gaji yang diberikan adalah 1/3 untuk PNS pria yang bersangkutan, 1/3 untuk bekas istrinya dan 1/3 untuk anakanaknya. Dalam undang-undang terkait peradilan agama, hal khusus ini tidak disebutkan sehingga secara umum tidak ada perbedaan antara PNS atau tidak dalam hal perceraian. Kekhususan terkait pemotongan gaji untuk nafkah anak dan syarat adanya izin melakukan perceraian dari atasan bagi PNS hanya diatur dalam Peraturan Pemerintah tentang PNS. ${ }^{2}$

\footnotetext{
${ }^{1}$ A. Basiq Djalil, Peradilan Agama di Indonesia, Jakarta: Kencana, 2006, hlm 9

${ }^{2}$ Muhammad Syarifuddin, Sri Turatmiyah dan Annalisa Yahanan, Hukum Perceraian, Jakarta: Sinar Grafika, 2014, hlm. 444.
}

Suloh Jurnal Program Studi Magister Hukum, Vol. 8, No. 1, April 2020, pp. 50 - 69 
Berbagai putusan yang dirilis oleh Mahkamah Agung memuat bahwa gugatan pihak lawan terhadap PNS untuk melaksanakan aturan tersebut ditolak dengan berpedoman pada Yurisprudensi Mahkamah Agung RI Nomor 11K/AG/2001 tanggal 10 Juli 2003 yang menyatakan bahwa pemberian $1 / 2$ bagian dari gaji Tergugat kepada Penggugat sebagaimana diatur dalam Pasal 8 Peraturan Pemerintah Nomor 10 Tahun 1983 yang diubah dengan Peraturan Pemerintah Nomor 45 Tahun 1990. Menyangkut Peraturan Disiplin Pegawai Negeri Sipil, bukan merupakan hukum acara Peradilan Agama, karena pemberian 1/2 gaji Tergugat kepada Penggugat merupakan Keputusan Pejabat Tata Usaha Negara.

Berdasarkan ketentuan yurisprudensi tersebut, ada inkonsistensi dalam pemberian kewenangan untuk memutus perkara perceraian dan akibat hukumnya. Di satu sisi, hukum memberikan kewenangan kepada pengadilan agama untuk menyelesaikan perkara perceraian antara orang yang beragama Islam sampai dengan menentukan akibat-akibat cerai yang ditimbulkan, namun di sisi lain, saat yang menjadi pihak dalam perkara cerai tersebut berprofesi sebagai PNS, akibat hukum yang ditimbulkan dari perceraian tersebut terhadap nafkah anak dengan berpedoman pada PP PNS menjadi kewenangan Pejabat Tata Usaha Negara meskipun PNS tersebut beragama Islam.

Rumusan masalah yang ingin dibahas dalam penelitian ini antara lain:

1. Bagaimana kekuatan putusan pengadilan agama terhadap pembebanan nafkah anak akibat perceraian seorang PNS?

2. Bagaimana pelaksanaan kewenangan pengadilan tata usaha negara dalam memutus perkara pembebaban nafkah anak akibat perceraian seorang PNS?

Adapun tujuan dari penelitian ini adalah:

1. Untuk memahami dan menganalisa kekuatan hukum putusan pengadilan agama terhadap pembebanan nafkah anak dari orang tua PNS yang bercerai.

2. Untuk menganalisis kewenangan Pengadilan Tata Usaha Negara dalam memutus perkara pembebanan nafkah anak dari orang tua PNS yang bercerai.

Manfaat yang ingin dicapai dalam penulisan tesis ini adalah:

1. Manfaat Teoritis

Penelitian ini diharapkan bermanfaat untuk pengembangan teori ilmu hukum dalam rangka menganalisis serta menjawab kegelisahan setiap unsur yang berkecimpung dalam penegakan hukum masalah ini.

2. Manfaat Praktis

Suloh Jurnal Program Studi Magister Hukum, Vol. 8, No. 1, April 2020, pp. 51 - 69 
Diharapkan penelitian ini dapat memberikan masukan atau manfaat bagi masyarakat, maupun pihak-pihak yang berkepentingan terkait dengan proses penyelesaian perkara perceraian dan akibat-akibatnya yang melibatkan pihak berprofesi PNS dan menghindari adanya konflik kewenangan antar lembaga.

Tiga landasan teoritis yang digunakan adalah grand theory, middle range theory, dan applied theory. Grand theory merupakan dasar lahirnya teori-teori lain. Teori ini dicoba dari penjelasan keseluruhan dari kehidupan sosial, sejarah, atau pengalaman manusia. Grand theory dalam penelitian ini adalah teori kewenangan. Berbicara mengenai teori kewenangan, artinya berbicara tentang kewenangan absolut dan relatif. Kewenangan absolut adalah kewenangan pengadilan untuk mengadili berdasarkan materi hukum (hukum materiil) sedangkan kewenangan relatif adalah kekuasaan mengadili berdasarkan wilayah atau daerah. ${ }^{3}$

Middle theory dalam penelitian ini adalah kewenangan hakim. Kewenangan hakim difasilitasi oleh kekuasaan kehakiman yang merdeka (independency of judiciary) yang merupakan syarat mutlak (conditio sine quanon) tegaknya hukum dan keadilan dan harus mendapat jaminan konstitusional yang kuat, sehingga hakim bebas dari pengaruh, bujukan, tekanan, ancaman atau gangguan secara langsung atau tidak langsung dalam melaksanakan tugas dan kewenangan peradilan. ${ }^{4}$ Sedangkan applied theory adalah teori yang siap diaktualisasikan dalam koseptualisasi yaitu teori kepastian hukum. Berkaitan dengan ini, setidaknya ada dua pengertian dari teori kepastian hukum, yaitu pertama adanya aturan yang bersifat umum membuat individu mengetahui perbuatan apa yang boleh atau tidak boleh dilakukan, dan kedua berupa keamanan hukum bagi individu dari kesewenangan pemerintah karena dengan adanya aturan hukum yang bersifat umum itu individu dapat mengetahui apa saja yang boleh dibebankan atau dilakukan oleh negara terhadap individu. ${ }^{5}$

Penelitian ini menggunakan penelitian hukum normatif dengan pendekatan perundang-undangan karena yang akan diteliti adalah berbagai aturan hukum yang menjadi fokus sekaligus tema sentral suatu penelitian. ${ }^{6}$ Metode penelitian hukum normatif adalah metode atau cara yang dipergunakan di dalam penelitian hukum yang

${ }^{3}$ Mushtofa, Sy., Kepaniteraan Peradilan Agama, Jakarta: Kencana, 2005, hlm. 9.

${ }^{4}$ Suparman Marzuki, Fair Trial, Hak Asasi Manusia, dan Pengawasan Hakim, Makalah pada Seminar Pemerkuatan Pemahaman Hak Asasi Manusia Untuk Hakim Seluruh Indonesia, Makassar: 2011, hlm. 3 .

5 Peter Mahmud Marzuki, Pengantar Ilmu Hukum, Kencana Pranada Media Group, Jakarta: 2008, hlm. 158.

6 Johnny Ibrahim, Teori dan Metodologi Penelitian Hukum Normatif, Malang: Bayumedia Publishing, 2010, hlm. 302.

Suloh Jurnal Program Studi Magister Hukum, Vol. 8, No. 1, April 2020, pp. 52 - 69 
dilakukan dengan cara meneliti bahan pustaka yang ada. ${ }^{7}$ Dengan kata lain penelitian ini merupakan penelitian kepustakaan (library reseach). ${ }^{8}$

Hasil penelitian ini dilakukan dengan menggunakan penelitian kualitatif yaitu penelitian yang lebih mengutamakan pada masalah proses dan makna/ persepsi, di mana penelitian ini diharapkan dapat mengungkap berbagai informasi kualitatif dengan deskripsi-analisis yang teliti dan penuh makna. ${ }^{9}$ Bentuk penelitian yang dipakai adalah tipe penelitian preskriptif analisis, yaitu mempelajari tujuan hukum, nilai-nilai keadilan, validitas aturan hukum, konsepkonsep hukum, dan norma-norma hukum. ${ }^{10}$

Pendekatan dalam penelitian ini menggunakan pendekatan undang-undang (statue approach), pendekatan kasus (case approach) dan pendekatan konseptual (conceptual approach) dalam menuliskan penelitian ini. Pendekatan undang-undang dilakukan dengan menelaah semua undang-undang dan regulasi yang bersangkut paut dengan isu hukum yang sedang ditangani. ${ }^{11}$

Penelitian ini dilakukan dengan mengumpulkan bahan hukum dengan pengelompokan sebagai berikut:

a. Bahan hukum primer, yaitu berasal dari peraturan perundang-undangan terdiri dari:

a) Undang-Undang Nomor 1 Tahun 1974 tentang Perkawinan.

b) Peraturan Pemerintah Nomor 9 Tahun 1975 tentang Pelaksanaaan UndangUndang Nomor 1 Tahun 1974 tentang Perkawinan.

c) Peraturan Pemerintah Nomor 10 Tahun 1983 tentang Izin Perkawinan dan Perceraian Bagi Pegawai Negeri Sipil yang telah diubah dengan Peraturan Pemerintah Nomor 45 Tahun 1990.

d) Kompilasi Hukum Islam.

e) Yurisprudensi Mahkamah Agung Nomor 11K/AG/2001.

b. Bahan hukum sekunder merupakan bahan hukum yang berasal dari buku-buku teks yang berisi prinsip-prinsip hukum dan pandangan-pandangan para sarjana. ${ }^{12}$

\footnotetext{
${ }^{7}$ Soerjono Soekanto dan Sri Mamudji, Penelitian Hukum Normatif Suatu Tinjauan Singkat, Cetakan ke-11, Jakarta: PT Raja Grafindo Persada, 2009, hlm 13-14.

${ }^{8}$ Mestika Zed, Metode Penelitian Kepustakaan, Jakarta: Yayasan Obor Indonesia, 2007, hlm. 3.

${ }^{9}$ Noeng Muhadjir, Metodologi Penelitian Kualitatif, Yogyakarta: Rake Sarasin, 1996, hlm. 243.

${ }^{10}$ Peter Mahmud Marzuki, Penelitian Hukum, Jakarta: Kencana, 2010, hlm. 22.

${ }^{11}$ Peter Mahmud Marzuki, Pengantar Ilmu Hukum, Jakarta: Kencana Pranada Media Group, 2008, hlm. 93.

${ }^{12}$ Ronny Hanitijo, Metode Penelitian Hukum, Jakarta: Ghalia Indo, 1993, hlm 43.
}

Suloh Jurnal Program Studi Magister Hukum, Vol. 8, No. 1, April 2020, pp. 53 - 69 
Bahan sekunder dalam penelitian ini didapat dari buku-buku teks, seminar, makalah, maupun karya ilmiah lainnya yang berkenaan dengan kajian ini.

c. Bahan hukum tersier, merupakan bahan hukum yang memberikan petunjuk maupun penjelasan terhadap bahan hukum primer dan bahan hukum sekunder. ${ }^{13}$ Bahan hukum tersier tersebut seperti kamus, ensiklopedi dan lain sebagainya.

Metode pengumpulan bahan yang dapat dilakukan terhadap penelitian hukum normatif adalah studi kepustakaan (library research), maksudnya adalah jika bahan yang diperlukan untuk menjawab masalah penelitian terdapat dalam bahan pustaka, maka kegiatan pengumpulan data itu disebut dengan literatur study. ${ }^{14}$ Bahan-bahan ini kemudian digunakan untuk mengkaji masalah yang menjadi bahan penelitian.

Mengolah bahan adalah merapikan bahan-bahan yang telah diperoleh terkait pembahasan yang dilakukan. Terhadap bahan tersebut, dilakukan pemilahan yang berkaitan dengan permasalahan yang dikaji agar bahan yang diperoleh dapat mendukung penyelesaian permasalahan yang diteliti.

\section{- KEWENANGAN PERADILAN AGAMA DAN TATA USAHA NEGARA}

\section{A. Teori Kewenangan}

Dalam hukum publik, wewenang berkaitan dengan kekuasaan. ${ }^{15}$ Kekuasaan dianggap bermakna sama dengan wewenang karena kekuasaan yang dimiliki oleh lembaga eksekutif, legislatif dan yudikatif yang ada di Indonesia adalah kekuasaan formal yang merupakan salah satu unsur dalam proses penyelenggaraan pemerintahan di suatu negara disamping unsur lain seperti hukum, keadilan, kejujuran, kebijakbestarian, kebajikan dan kewenangan (wewenang). ${ }^{16}$

Istilah wewenang digunakan dalam bentuk kata benda dan sering disejajarkan dengan istilah bevoegheid dalam istilah hukum Belanda. Jika dicermati ada sedikit perbedaan antara istilah kewenangan dengan istilah bevoegheid. Perbedaan tersebut terletak pada karakter hukumnya. Istilah bevoegheid digunakan dalam konsep hukum publik maupun dalam hukum privat. Dalam konsep hukum kita istilah

${ }^{13}$ Soerjono Soekanto, Penelitian Hukum Normatif, Jakarta: PT. Raja Grafindo Persada, 2006, hlm 61.

${ }^{14}$ Rianto Adi, Metodologi Penelitian Sosial dan Hukum, Jakarta: Granit, 2004, hlm 72.

15 Philipus M. Hadjon, Tentang Wewenang, Yuridika No.5\&6 Tahun XII, SeptemberDesember, 1997, hlm. 1.

${ }^{16}$ Rusadi Kantaprawira, Hukum dan Kekuasaan, Yogyakarta: Universitas Islam Indonesia, 1998, hlm. 37-38.

Suloh Jurnal Program Studi Magister Hukum, Vol. 8, No. 1, April 2020, pp. 54 - 69 
kewenangan atau wewenang seharusnya digunakan dalam konsep hukum publik. ${ }^{17}$ Oleh karena itulah, dalam konsep hukum publik, wewenang berkaitan dengan kekuasaan. $^{18}$ Sedangkan F.P.C.L. Tonner dalam Ridwan HR., berpendapat "Overheidsbevoegdheid wordt in dit verband opgevad als het vermogen om positief recht vast te srellen en Aldus rechtsbetrekkingen tussen burgers onderling en tussen overhead en te scheppen" (kewenangan pemerintah dalam kaitan ini dianggap sebagai kemampuan untuk melaksanakan hukum positif, dan dengan begitu dapat diciptakan hubungan hukum antara pemerintahan dengan warga negara). ${ }^{19}$

\section{B. Kewenangan Peradilan}

Di Indonesia, kekuasaan kehakiman diatur dalam Undang-Undang Nomor 48 Tahun 2009 tentang Kekuasaan Kehakiman. Kekuasaan kehakiman dilakukan oleh sebuah Mahkamah Agung dan badan peradilan yang berada di bawahnya dalam lingkungan peradilan umum, lingkungan peradilan agama, lingkungan peradilan militer, lingkungan peradilan tata usaha negara, dan oleh sebuah Mahkamah Konstitusi. ${ }^{20}$ Badan-badan peradilan dalam 4 (empat) lingkungan peradilan tersebut memiliki kekuasaan yuridiksi menerima, memeriksa, memutus, dan menyelesaikan suatu perkara yang diajukan kepadanya. ${ }^{21}$

Yurisdiksi dalam bahasa Indonesia berasal dari Bahasa Inggris "jurisdiction" yang berasal dari bahasa Latin "yurisdictio", yang terdiri atas dua suku kata, yuris yang berarti kepunyaan menurut hukum, dan diction yang berarti ucapan, sabda, sebutan, firman. Dalam Kamus Besar Bahasa Indonesia, yurisdiksi memiliki 2 (dua) pengertian, yaitu: ${ }^{22}$

1) Kekuasaan mengadili, lingkup kekuasaan kehakiman dan peradilan;

2) Lingkungan hak dan kewajiban, serta tanggung jawab di suatu wilayah atau lingkungan kerja tertentu; kekuasaan hukum.

\section{Peradilan Agama}

\footnotetext{
${ }^{17}$ Phillipus M. Hadjon, Op. Cit., hlm. 20

${ }^{18}$ Ibid., hlm. 1.

${ }^{19}$ Ridwan HR, Hukum Administrasi Negara, Jakarta: Rajawali Pers, 2006, hlm. 100

${ }^{20}$ Pasal 18 Undang-Undang Nomor 48 Tahun 2009 tentang Kekuasaan Kehakiman.

${ }^{21}$ Z. A. Sangadji, Op. Cit., hlm. 2-3.

${ }^{22}$ Departemen Pendidikan Nasional, Op. Cit., hlm. 1278
}

Suloh Jurnal Program Studi Magister Hukum, Vol. 8, No. 1, April 2020, pp. 55 - 69 
Kelembagaan Peradilan Agama sebagai wadah, dan hukum Islam sebagai muatan atau isi pokok pegangan dalam menyelesaikan dan memutus perkara, tidak dapat dipisahkan. Apalagi pada masa kekuasaan kerajaan Islam lembaga peradilan agama termasuk bagian yang tak terpisahkan dengan pemerintahan umum, sebagai penghulu kraton yang mengurus keagamaan Islam dalam semua aspek kehidupan.

Bidang perkara yang menjadi kewenangan Peradilan Agama diatur dalam Undang-Undang Nomor 7 Tahun 1989 tentang Peradilan Agama yang kemudian diubah dengan Undang-Undang Nomor 3 Tahun 2006 dan perubahan kedua dengan Undang-Undang Nomor 50 Tahun 2009. Dalam Undang-Undang Nomor 7 Tahun 1989, perkara-perkara yang menjadi kewenangan Peradilan Agama tersebut termuat dalam Pasal 49 antara lain:

1) Perkawinan;

2) Kewarisan, wasiat, dan hibah yang dilakukan berdasarkan hukum Islam; dan

3) Wakaf dan sedekah.

Setelah adanya Undang-Undang Nomor 3 Tahun 2006 tentang Perubahan atas Undang-Undang Nomor 7 Tahun 1989 tentang Peradilan Agama, perkara yang menjadi kewenangan Peradilan Agama ditambah menjadi:

1) perkawinan;

2) waris;

3) wasiat;

4) hibah;

5) wakaf;

6) zakat;

7) infaq;

8) shadaqah; dan

9) ekonomi syari'ah.

\section{Peradilan Tata Usaha Negara}

Sistem Peradilan Tata Usaha Negara bertujuan untuk melaksanakan fungsi pengawasan yudisial terhadap tindakan hukum tata usaha Negara. ${ }^{23}$ Pada awalnya Undang-Undang Dasar 1945 tidak mengenal eksistensi Peradilan Tata Usaha Negara (PTUN). Dalam undang-undang tersebut dinyatakan bahwa tujuan adanya PTUN

${ }^{23}$ W. Riawan Tjandra, Perbandingan Sistem Peradilan Tata Usaha Negara dan Conseil d'etat sebagai Institusi Pengawas Tindakan Hukum Tata Usaha Negara, Jurnal Hukum IUS QUIA IUSTUM

Suloh Jurnal Program Studi Magister Hukum, Vol. 8, No. 1, April 2020, pp. 56 - 69 
dimaksudkan untuk menegakkan keadilan, kebenaran, ketertiban, dan kepastian hukum, sehingga dapat memberikan pengayoman kepada masyarakat, khususnya dalam hubungan antara Badan atau Pejabat Tata Usaha Negara dengan masyarakat. Selain itu keberadaan PTUN adalah untuk membina, menyempurnakan, dan menertibkan aparatur di bidang Tata Usaha Negara, agar mampu menjadi alat yang efisien, efektif, bersih, serta berwibawa, dan yang dalam melaksanakan tugasnya selalu berdasarkan hukum dengan dilandasi semangat dan sikap pengabdian untuk masyarakat.

Peradilan Tata Usaha Negara berwenang memeriksa, mengadili, memutus, dan menyelesaikan sengketa tata usaha negara sesuai dengan ketentuan peraturan perundang-undangan. ${ }^{24}$ Kompetensi absolut Pengadilan TUN diatur dalam Pasal 1 angka 10 Undang-Undang Nomor 51 Tahun 2009 tentang Perubahan Kedua UndangUndang Nomor 5 Tahun 1986 tentang Peradilan Tata Usaha Negara, yang menyebutkan:

"Sengketa tata usaha Negara adalah sengketa yang timbul dalam bidang Tata Usaha Negara antara orang atau Badan Hukum Perdata dengan Badan atau Pejabat tata usaha negara, baik di pusat maupun di daerah, sebagai akibat dikeluarkannya Keputusan tata usaha negara, termasuk sengketa kepegawaian berdasarkan peraturan perundang-undangan yang berlaku."

Keputusan Tata Usaha Negara yang dimaksud di atas menurut ketentuan Pasal 1 angka 9 Undang-Undang Nomor 51 Tahun 2009 adalah suatu penetapan tertulis yang dikeluarkan oleh Badan/ Pejabat TUN yang berisi tindakan hukum TUN berdasarkan peraturan perundang-undangan yang berlaku, yang bersifat konkrit, individual dan final sehingga menimbulkan akibat hukum bagi seseorang atau badan hukum perdata. Dari rumusan pasal tersebut, persyaratan keputusan TUN yang dapat menjadi obyek di Pengadilan TUN meliputi:

1) Penetapan tertulis;

2) Dikeluarkan oleh Badan/Pejabat TUN;

3) Berisi tindakan hukum TUN;

4) Berdasarkan peraturan perundang-undangan yang berlaku;

5) Bersifat konkrit, individual dan final;

6) Menimbulkan akibat hukum bagi seseorang atau badan hukum perdata.

NO. 3 VOL. 20 JULI 2013, hlm. 424, https://media.neliti.com/media/publications/84722-none366328b1.pdf, , diakses pada tanggal 1 Agustus 2019 pukul 11.30 WIB.

${ }^{24}$ Pasal 25 ayat (5) Undang-Undang Nomor 48 Tahun 2009 tentang Kekuasaan Kehakiman

Suloh Jurnal Program Studi Magister Hukum, Vol. 8, No. 1, April 2020, pp. 57 - 69 


\section{- PENGATURAN PERCERAIAN PEGAWAI NEGERI SIPIL DI INDONESIA}

\section{A. Makna Perceraian}

Perceraian merupakan pilihan hukum antara pasangan yang telah menikah setelah mereka tidak bisa menyatukan perbedaan yang timbul antara keduanya. ${ }^{25}$ Hukum Islam mensyari'atkan tentang putusnya perkawinan melalui perceraian sebagai jalan terakhir apabila dalam rumah tangga tidak bisa ditemukan lagi keharmonisan dan kerukunan, hanya perceraianlah yang menjadi satu-satunya jalan yang harus ditempuh, namun demikian bukan berarti agama Islam menyukai terjadinya perceraian dari suatu perkawinan. Bahkan harus diingat bahwa perceraian pun tidak boleh dilaksanakan setiap saat yang dikehendaki, sehingga hanya dalam keadaan yang tidak dapat dihindari itu sajalah, perceraian yang dibolehkan dalam syari'at. ${ }^{26}$ Yang tidak kalah urgensinya adalah alasan-alasan yang mendasari putusnya perkawinan itu serta sebab-sebab apa terjadi perceraian. ${ }^{27}$

\section{B. Aturan Hukum Perceraian}

Di dalam ketentuan Undang-Undang Nomor 1 Tahun 1974 tentang Perkawinan, antara lain diatur dalam Pasal 39 sampai dengan Pasal 41 dan dalam Peraturan Pemerintah Nomor 9 Tahun 1975 tentang Pelaksanaan Undang-Undang Nomor 1 Tahun 1974 tentang Perkawinan dalam Pasal 14 sampai dengan Pasal 36, perceraian diatur dengan cara cerai gugat dan cerai talak, perceraian dapat terjadi atas dasar caracara tersebut, yang pelaksanaannya diatur dalam perkawinan menurut agama Islam akan menceraikan istrinya, mengajukan surat kepada pengadilan, di tempat tinggalnya yang berisi pemberitahuan bahwa ia bermaksud menceraikan istrinya disertai dengan alasan-alasan serta meminta kepada pengadilan agar diadakan sidang untuk keperluan itu. ${ }^{28}$ Ketentuan umum mengenai pengajuan gugatan ke pengadilan

${ }^{25}$ Amina Wadud Muhsin, Wanita di Dalam Al-Qur'an, terj. Yadiar Radianti, Bandung: Fajar Bhakti, 1994, hlm. 106.

26 Titik Triwulan Tutik, Hukum Perdata dalam Sistem Hukum Nasional, Jakarta: Kencana, 2012, hlm. 130-131.

27 Martiman Prodjohamidjojo, Penasehat Dan Organisasi Bantuan Hukum, Jakarta: Ghalia Indonesia, 2004, hlm. 41.

${ }^{28}$ Shoedharyo Soimin, Hukum Orang dan Keluarga Perspektif Hukum Perdata/BW Hukum Islam dan Hukum Adat, Jakarta: Sinar Grafika, 2004, hlm. 65.

Suloh Jurnal Program Studi Magister Hukum, Vol. 8, No. 1, April 2020, pp. 58 - 69 
telah diatur dalam Bab IX Het Herziene Indonesisch Reglement (HIR)/ Rechtreglement voor de Buitengewesten (R.Bg)., yang merupakan salah satu sumber hukum acara perdata yang berlaku di pengadilan. Jadi, perceraian hanya dapat berlaku dan diakui secara hukum jika dilakukan

\section{Akibat Hukum Perceraian}

Perubahan status hukum dari perkawinan kepada perceraian akan menimbulkan berbagai akibat hukum. Oleh karena itu, perceraian hanya dapat terjadi apabila dilakukan di depan pengadilan, baik itu karena suami yang telah menjatuhkan cerai (talak), ataupun karena istri yang menggugat cerai atau memohonkan hak talak sebab sighat taklik talak. Tujuannya untuk melindungi segala hak dan kewajiban yang timbul sebagai dari akibat hukum atas perceraian tersebut. ${ }^{29}$ Demikian juga yang tertuang dalam aturan hukum Pasal 39 Undang-Undang Nomor 1 Tahun 1974 tentang Perkawinan jo. Pasal 115 Kompilasi Hukum Islam. Pengadilan sebagai perpanjangan tangan pemerintah dalam hal pelaksanaan hukum juga dituntut untuk mampu memberikan keadilan dan jalan keluar bagi orang-orang yang terlibat dalam perceraian pasca cerai dijatuhkan seperti istri dan anak. Menurut Madani, akibat hukum putusnya perkawinan antara lain: ${ }^{30}$

1. Hubungan suami istri berubah, menjadi rekan hanya dalam mengasuh dan membesarkan anak, bukan sebegaimana hubungan suami istri seperti dulu.

2. Suami wajib memberi mut'ah, yaitu kenang-kenangan untuk istri sesuai kemampuan dan biasanya diukur dari berapa lama masa perkawinan berjalan.

3. Melunasi mahar, jika itu hutang dan nafkah yang belum dibayarkan selama perkawinan berjalan.

4. Terhadap istri akan berlaku masa iddah, masa dimana istri tidak boleh dipinang atau dinikahi laki-laki lain dengan pertimbangan sewaktu-waktu suami berubah pikiran dan ingin kembali yang keinginan itu disambut baik oleh istri, maka tidak perlu nikah ulang.

5. Penentuan pemeliharaan anak hasil perkawinan baik secara materi maupun pengasuhan yang harus dipenuhi.

\section{Aturan Hukum Perceraian Pegawai Negeri Sipil}

\footnotetext{
${ }^{29}$ Budi Susilo, Op. Cit., hlm. 17.

${ }^{30}$ Madani, Hukum Perkawinan Islam di Indonesia Modern, Yogyakarta: Graha Ilmu, 2011, hlm. 30 .
}

Suloh Jurnal Program Studi Magister Hukum, Vol. 8, No. 1, April 2020, pp. 59 - 69 
Aturan perceraian bagi pegawai negeri sipil, antara lain termuat dalam aturanaturan berikut:

1. Peraturan Pemerintah Nomor 45 Tahun 1990 tentang Perubahan Atas Peraturan Pemerintah Nomor 10 Tahun 1983 tentang Izin Perkawinan dan Perceraian bagi Pegawai Negeri Sipil.

Prosedur perceraian menurut Perauran Pemerintah ini termuat dalam Pasal 3 ayat (1), (2) dan (3) yang berbunyi:

1) Pegawai Negeri Sipil yang akan melakukan perceraian wajib memperoleh izin atau surat keterangan lebih dahulu dari pejabat;

2) Bagi Pegawai Negeri sipil yang berkedudukan sebagai penggugat atau bagi pegawai negeri sipil yang berkedudukan sebagai tergugat untuk memperoleh izin atau surat keterangan sebagaimana dimaksud alam ayat harus mengajukan permintaan secara tertulis;

3) Dalam surat permintaan izin atau pemberitahuan adanya gugatan perceraian untuk mendapatkan surat keterangan, harus dicantumkan alasan yang lengkap yang mendasarinya."

2. Peraturan Pemerintah Nomor 53 Tahun 2010 tentang Disiplin Pegawai Negeri Sipil.

Surat Edaran Kepala Badan Administrasi Kepegawaian Negara Nomor 08/SE/1983.

\section{- PEMBEBANAN NAFKAH ANAK AKIBAT PERCERAIAN PNS}

A. Putusan Pengadilan Agama Terhadap Nafkah Anak PNS Cerai

Dalam Pasal 41 ayat (1) Undang-Undang Nomor 1 Tahun 1974 tentang Perkawinan, disebutkan adanya kewajiban orang tua terhadap anak yaitu kedua orang tua wajib memelihara dan mendidik anak-anak mereka sebaik-baiknya, sedangkan dalam ayat (2) dikatakan bahwa kewajiban orang tua yang dimaksud dalam ayat 1 berlaku sampai anak itu kawin atau dapat berdiri sendiri meskipun perkawinan antar keduanya putus. Namun, seringkali akibat perceraian kedua orang tuanya, banyak anak yang kepentingannya pada akhirnya terbengkalai.

Kewajiban memberikan perlindungan hukum baik secara materil maupun tidak terhadap anak yang menjadi korban perceraian dari kedua orang tuanya ini berlaku bagi semua warga Negara Indonesia yang melakukan perceraian, termasuk Pegawai Negeri Sipil. Namun sebagaimana telah dijelaskan sebelumnya, bagi PNS berlaku aturan tambahan yaitu Peraturan Pemerintah Nomor 45 Tahun 1990 tentang Suloh Jurnal Program Studi Magister Hukum, Vol. 8, No. 1, April 2020, pp. 60 - 69 
Perubahan Atas Peraturan Pemerintah Nomor 10 Tahun 1983 tentang Izin Perkawinan dan Perceraian bagi Pegawai Negeri Sipil.

Dalam Undang-Undang Nomor 14 Tahun 1984 tentang Mahkamah Agung yang telah diubah dengan Undang-Undang Nomor 5 Tahun 2004 dan perubahan kedua dengan Undang-Undang Nomor 3 Tahun 2009, dikatakan bahwa putusan dari semua lingkungan peradilan termasuk Peradilan Agama dapat mengajukan permohonan kasasi ke Mahkamah Agung, ini membuktikan bahwa putusan pengadilan agama mempunyai kekuatan hukum yang sama dengan putusan dari badan peradilan lainnya, termasuk putusannya terhadap pembebanan nafkah terhadap anak PNS cerai selama putusan tersebut telah berkekuatan hukum tetap dengan pertimbangan sebagai berikut:

1. Peradilan agama mempunyai kewenangan absolut terhadap perkara cerai (vide. Pasal 49 Undang-Undang Peradilan Agama).

2. Pembebanan nafkah untuk anak dari PNS cerai merupakan akibat hukum yang timbul dalam perkara cerai sehingga pengadilan sebagai salah satu jalan memohon keadilan mempunyai kewenangan untuk menerima perkara tersebut sampai penyelesaiannya termasuk eksekusi (pelaksanaan putusan).

3. Dalam Undang-Undang Perkawinan jelas disebutkan bahwa ayah bertanggung jawab terhadap nafkah anaknya baik dalam masa perkawinan maupun sampai terjadinya perceraian.

4. Dalam Peraturan Pemerintah tentang PNS juga ditetapkan kewajiban ayah PNS untuk tetap memberikan nafkah kepada anaknya sebenyak sepertiga gaji.

\section{B. Kewenangan Pengadilan Tata Usaha Negara Memutus Pembebanan Nafkah Anak}

Kompetensi absolut peradilan tata usaha Negara adalah mengadili dan menyelesaikan sengketa dalam bidang Tata Usaha Negara antara orang atau Badan Hukum Perdata dengan Badan atau Pejabat tata usaha negara, baik di pusat maupun di daerah, sebagai akibat dikeluarkannya Keputusan tata usaha negara, termasuk sengketa kepegawaian berdasarkan peraturan perundang-undangan yang berlaku. Dari pengertian tersebut, jelas bahwa kriteria perkara yang menjadi kewenangan Pengadilan Tata Usaha Negara antara lain:

1. Sengketa kepegawaian bersifat perdata;

Suloh Jurnal Program Studi Magister Hukum, Vol. 8, No. 1, April 2020, pp. 61 - 69 
2. Antara orang atau badan hukum perdata dengan badan atau pejabat tata usaha Negara; dan

3. Terkait keputusan tata usaha Negara.

Yurisprudensi Mahkamah Agung RI Nomor 11K/AG/2001 tanggal 10 Juli 2003 yang menyatakan bahwa pemberian $1 / 2$ bagian dari gaji Tergugat kepada Penggugat sebagaimana diatur dalam Pasal 8 Peraturan Pemerintah Nomor 10 Tahun 1983 yang diubah dengan Peraturan Pemerintah Nomor 45 Tahun 1990 bukan merupakan hukum acara Peradilan Agama dikarenakan hal tersebut merupakan Keputusan Pejabat Tata Usaha Negara, dianggap kurang tepat jika dilihat dari sudut pandang sebagai berikut:

a. Segi kedudukan hukum peradilan.

Dalam Undang-Undang Dasar 1945, jelas dikatakan bahwa kekuasaan kehakiman dijalankan oleh sebuah Mahkamah Agung dan badan peradilan yang berada di bawahnya dalam lingkungan peradilan umum, lingkungan peradilan agama, lingkungan peradilan militer, lingkungan peradilan tata usaha Negara, dan oleh sebuah Mahkamah Konstitusi. Maka, untuk memahami tujuan kekuasaan kehakiman itu, perlu dipelajari sejarah kekuasaan kehakiman itu sendiri.

Putusan yang baik adalah putusan yang mengandung kepastian, keadilan dan kemanfaatan hukum serta dapat dieksekusi jika putusan tersebut tidak dijalankan secara sukarela. Peraturan Pemerintah yang menjadi aturan hukum bagi PNS yang bercerai, tidak mengatur secara tegas bahwa proses eksekusi biaya pembebanan nafkah anak PNS yang bercerai harus melalui peradilan tata usaha Negara, oleh karena demikian, hakim dapat menginterpretasi aturan hukum sesuai dengan penalaran yang berdasar hukum.

b. Segi kewenangan absolut

Peradilan agama dan peradilan tata usaha Negara sebagai bagian dari kekuasaan kehakiman, telah diberi amanat melalui Undang-Undang Kekuasaan Kehakiman untuk menerima, memeriksa, mengadili dan menyelesaikan perkara yang diajukan kepadanya. Arti penting kekuasaan kehakiman adalah untuk memutus sengketa hukum yang timbul antara anggota masyarakat satu sama lain atau antara anggota masyarakat dengan pihak pemerintah. Agar tidak terjadi penyimpangan dan kekacauan dalam masyarakat, maka masing-masing badan peradilan tersebut diberi kewenangan yang berbeda, baik antara badan peradilan yang berbeda dengan jenis perkara yang berbeda (kompetensi absolut) maupun antara badan peradilan yang sama dengan wilayah hukum yang berbeda (kompetensi relatif).

Suloh Jurnal Program Studi Magister Hukum, Vol. 8, No. 1, April 2020, pp. 62 - 69 
Pembagian kewenangan ini akan bermuara pada terbitnya putusan yang berkepastian, berkeadilan dan berkemanfaatan hukum demi terwujudnya ketertiban umum. Jika kemudian pembebanan nafkah anak PNS yang bercerai bukan merupakan hukum acara peradilan agama, maka ada ketumpangtindihan kompetensi antara peradilan agama dan peradilan tata usaha Negara terkait perkara ini yang nantinya akan merugikan dan membingungkan masyarakat banyak terutama para PNS. Empat badan peradilan yang berada di bawah Mahkamah Agung mempunyai kedudukan yang sama dengan kompetensi absolut yang berbeda-beda sesuai dengan aturan hukum masing-masing sehingga setiap putusan dari masing-masing badan peradilan tersebut mempunyai kekuatan hukum yang sama.

c. Segi Asas Peradilan

Dalam Undang-Undang Kekuasaan Kehakiman, telah dinyatakan bahwa peradilan membantu pencari keadilan dan berusaha mengatasi segala hambatan dan rintangan untuk dapat tercapainya peradilan yang sederhana, cepat dan biaya ringan. Pengertian terhadap asas ini dapat dilihat pada bagian penjelasan undang-undang yang menyebutkan bahwa "sederhana" adalah pemeriksaan dan penyelesaian perkara dilakukan dengan cara efesien dan efektif dan "biaya ringan" adalah biaya perkara yang dapat dijangkau oleh masyarakat.

Perkara perceraian menyangkut orang yang beragama Islam dan dilaksanakan secara Islam baik PNS ataupun tidak, merupakan kompetensi absolut Pengadilan Agama, yang dalam hal ini di Aceh bernama Mahkamah Syar'iyah. Segala akibat hukum yang merupakan kelanjutan dari perkara perceraian dengan mempertimbangkan kepastian, keadilan dan kemanfaatan hukum haruslah juga diputus oleh pengadilan asal yang memutusnya yaitu Pengadilan Agama/ Mahkamah Syar'iyah. Pembebanan nafkah anak dari orang tua yang bercerai baik PNS maupun tidak merupakan salah satu bentuk akibat hukum adanya perceraian.

\section{d. Segi Sistem Hukum yang Berlaku di Indonesia}

Sistem hukum Indonesia pada dasarnya adalah sistem hukum civil law, meskipun tidak dapat dijamin sepenuhnya demikian karena dalam pelaksanaannya terkadang masih menggunakan common law sebagaimana yang dikatakan oleh Satjipto Rahardjo bahwa di dunia ini kita tidak jumpai satu sistem hukum saja, melainkan lebih dari satu. ${ }^{31}$ Dari sisi pembagian kekuasaan, dapat disimpulkan bahwa Indonesia lebih banyak menggunakan sistem civil law dalam kehidupan bernegaranya. Ada tiga karakteristik dari sistem hukum civil law, yaitu:

${ }^{31}$ Satjipto Rahardjo, Ilmu Hukum, Bandung: PT Citra Aditya Bakti, 1991, hlm. 235.

Suloh Jurnal Program Studi Magister Hukum, Vol. 8, No. 1, April 2020, pp. 63 - 69 
1. Adanya sistem kodifikasi

Menurut sistem hukum ini, kodifikasi diperlukan untuk menciptakan keseragaman hukum dalam dan di tengah-tengah keberagaman hukum.

2. Hakim tidak terikat dengan preseden atau doktrin stare decicis, sehingga undangundang menjadi rujukan hukumnya yang utama.

Pemisahaan antar kekuasaan menjadi tiga pilar, eksekutif, legislatif dan yudikatif membuat ketiga pilar tersebut tidak dapat mencampuri urusan kekuasaan lainnya, dengan cara tersebut maka terbentuklah yurisprudensi.

3. Sistem peradilannya bersifat inkuisitorial

Dalam sistem ini hakim mempunyai peranan yang besar dalam mengarahkan dan memutus suatu perkara. Hakim bersifat aktif dalam menemukan fakta hukum dan cermat dalam menilai bukti.

Tidak seperti sistem hukum common law yang menjadikan yurisprudensi sebagai sumber hukum, sistem hukum civil law tidak menjadikan yurisprudensi sebagai sumber rujukan sehingga hakim tidak perlu terikat pada yurisprudensi selama hakim yang bersangkutan mempunyai analisa hukumnya sendiri untuk memberikan putusan yang berkepastian, berkeadilan dan berkemanfaatan bagi para pencari keadilan. Indonesia adalah salah satu Negara yang lebih banyak menganut sistem hukum civil law dalam penegakan hukumnya mengatur bahwa yurisprudensi bukanlah salah satu hierarki perundangan yang wajib dijadikan rujukan sumber hukum untuk memutus suatu perkara, yurisprudensi dapat dijadikan acuan sepanjang penalaran hukum yang digunakan sesuai dengan penalaran hukum hakim yang memutus suatu perkara.

\section{- $\quad$ Penutup}

\section{A. Kesimpulan}

Dari berbagai pembahasan dalam bab-bab sebelumnya, dapat diambil poin penting sebagai berikut:

1. Mengingat kewenangan pengadilan agama salah satunya adalah bidang perkawinan termasuk di dalamnya berbagai permasalahan seputar perkawinan seperti perceraian, maka akibat-akibat yang ditimbulkan dari perceraian itu sendiri sudah sepatutnya menjadi kewenangan pengadilan agama. Meskipun dalam berbagai aturan terkait perceraian terutama PNS tidak mengamanatkan lembaga mana yang dapat memutus pemotongan gaji akibat pembebanan nafkah untuk anak, namun dengan mengingat bahwa pembebanan nafkah adalah akibat

Suloh Jurnal Program Studi Magister Hukum, Vol. 8, No. 1, April 2020, pp. 64 - 69 
hukum dari perceraian, maka pengadilan agama jugalah yang berwenang mengadilinya. Kekuatan hukum putusan pengadilan agama sama dengan pengadilan bidang peradilan lainnya karena pengadilan agama merupakan salah satu peradilan yang setara dengan peradilan lain dalam kekuasaan kehakiman selama dalam putusan tersebut mengandung amar condemnatoir dan sudah berkekuatan hukum tetap sehingga putusan tersebut dapat dijalankan atau dapat diekseskusi jika tidak dijalankan secara sukarela.

2. Yurisprudensi Mahkamah Agung yang menjadi titik tolak penelitian ini hanya berbunyi terkait pemberian nafkah terhadap mantan isteri yang merupakan wewenang pejabat tata usaha Negara, namun berpedoman pada aturan perceraian menyangkut PNS, maka aturan tersebut juga berlaku untuk nafkah anak. Penelitian ini menyimpulkan bahwa pengadilan tata usaha Negara tidak mempunyai kewenangan dalam memutus pembebanan nafkah untuk anak dari orangtua PNS yang bercerai karena pengadilan tata usaha Negara tidak diberi wewenang untuk itu. Terkait dengan bunyi Yurisprudensi, sistem hukum yang dianut Indonesia tidak menjadikan yurisprudensi sebagai salah satu sumber hukum sehingga selama hakim yang mengadili perkara sependapat dengan yurisprudensi, yurisprudensi dapat diajdikan salah satu pertimbangan memutus perkara, demikian pula sebaliknya, jika tidak sependapat, hakim tidak wajib mengikuti pertimbangan hukum yang ada di yurisprudensi. Pengadilan Tata Usaha Negara juga tidak mempunyai wewenang untuk mengesahkan putusan pengadilan agama terkait pembebanan nafkah tersebut.

\section{B. Saran}

Berpedoman pada pembahasan di atas, maka dapat disarankan hal-hal sebagai berikut:

1. Pembebanan nafkah anak dari orangtua PNS yang bercerai merupakan kewenangan peradilan agama sehingga hakim pengadilan agama tidak perlu ragu untuk memutus perkara pembebanan nafkah anak dari orangtua PNS Islam yang bercerai karena diberi wewenang untuk itu dalam undang-undang selama dalam persidangannya terbukti. Hakim harus tetap berpedoman pada asas peradilan cepat, sederhana dan biaya ringan.

2. Kepada lembaga-lembaga pemerintah yang aparatur sipil Negara-nya bercerai

Suloh Jurnal Program Studi Magister Hukum, Vol. 8, No. 1, April 2020, pp. 65 - 69 
dan dihukum untuk memberi nafkah anak melalui pemotongan gaji, harus dilakukan sesuai dengan amar putusan yang ada karena putusan yang telah berkekuatan hukum tetap dapat dieksekusi sesuai dengan amanat undangundang dan kekuatan hukum putusan peradilan agama sama dengan peradilan lainnya.

\section{DAFTAR PUSTAKA}

\section{A. Buku}

Abdullah, Rozali, Hukum Acara Peradilan Tata Usaha Negara, Jakarta: PT. Raja Grafindo Persada, 2005.

Admosudirjo, Prajudi, Hukum Administrasi Negara, Jakarta: Ghalia Indonesia, 1988.

Ali, Mohammad Daud, Pengantar Ilmu Hukum dan Tata Hukum Islam di Indonesia, Jakarta: PT Raja Grafindo Persada, 2005.

Al-Kahlani, Muhammad Ismail, Subul Al-Salam, jilid 3., Bandung: Dahlan, 2009.

Arto, A. Mukti, Praktek Perkara Perdata pada Pengadilan Agama, Yogyakarta: Pustaka Pelajar, 2004.

Basah, Sjachran, Mengenal Peradilan di Indonesia, Jakarta: Raja Grafindo Persada, 1995.

Basri, Cik Hasan, Peradilan Agama di Indonesia, Jakarta: PT Raja Grafindo Persada, 2003.

Buana, Mirza Satria, Hukum Internasiona Teori dan Praktek, Bandung: Nusamedia, 2007.

Csbafi, Anthony, The Concept of State Jusrisdiction in International Space Law, The Hague.

Djalil, A. Basiq, Peradilan Agama di Indonesia, Jakarta: Kencana, 2006.

Djatmika, Sastra dan Marsono, Hukum Kepegawaian di Indonesia, Jakarta: Djatmika, 1995.

Hadjon, Philipus M., Perlindungan Hukum Bagi Rakyat di Indonesia, Cetakan Pertama, Surabaya: PT. Bina Ilmu, 1987.

Harahap, M. Yahya, Hukum Acara Perdata Tentang Gugatan, Persidangan, Penyitaan, Pembuktian, dan Putusan Pengadilan, Jakarta : Sinar Grafika, 2016. , Hukum Acara Perdata, Jakarta: Sinar Grafika, 2009.

, Kedudukan Kewenangan Dan Acara Peradilan Agama UU No. 7 Tahun 1989, Ed. ke-2., Cet. IV, Jakarta: Sinar Grafika, 2007.

HR, Ridwan, Hukum Administrasi Negara, Jakarta: Rajawali Pers, 2006.

Ibrahim, Johnny, Teori dan Metodologi Penelitian Hukum Normatif, Malang: Bayumedia Publishing, 2010.

Lotulung, Paulus Efendie, Himpunan Makalah Asas-Asas Umum Pemerintahan yang

Suloh Jurnal Program Studi Magister Hukum, Vol. 8, No. 1, April 2020, pp. 66 - 69 
Baik, Bandung: Citra Aditya Bakti, 1994.

Madani, Hukum Perkawinan Islam di Indonesia Modern, Yogyakarta: Graha Ilmu, 2011.

Marzuki, Peter Mahmud, Penelitian Hukum, Jakarta: Kencana, 2010.

Group, 2008. , Pengantar Ilmu Hukum, Jakarta: Kencana Pranada Media

Muhadjir, Noeng, Metodologi Penelitian Kualitatif, Yogyakarta: Rake Sarasin, 1996, hlm. 243.

Muhsin, Amina Wadud, Wanita di Dalam Al-Qur'an, terj. Yadiar Radianti, Bandung: Fajar Bhakti, 1994.

Nasution, Bahder Johan, Sri Warjiyati, Hukum Perdata Islam, Surabaya: Mandar Maju, 1997.

Prakoso, Djoko \& I Ketut Murtika, Pembinaan Pegawai Negeri Sipil, Jakarta: Bina Aksara, 1987.

Prijodarminto, Soegeng, Duri dan Mutiara dalam Kehidupan Perkawinan PNS, Jakarta: PT Pradnya Paramita, 1994.

Prodjohamidjojo, Martiman, Penasehat Dan Organisasi Bantuan Hukum, Jakarta: Ghalia Indonesia, 2004.

Rahardjo, Satjipto, Hukum Progressif : Sebuah Sintesa Hukum Indonesia, Cet. I., Jakarta: Genta Publishing, 2009. , Ilmu Hukum, Bandung: PT Citra Aditya Bakti, 1991.

Ramulyo, Moh. Idris, Hukum Perkawinan Islam, Jakarta: PT. Bumi Aksara, 2004.

Rasjidi, Lili, Hukum Perkawinan dan Perceraian di Malaysia dan Indonesia, Bandung: Alumni, 1982.

Rasyid, Roihan, A., Hukum Acara Peradilan Agama, Jakarta: PT. Raja Grafindo Persada, 2010.

Soekanto, Soerjono dan Sri Mamudji, Penelitian Hukum Normatif Suatu Tinjauan Singkat, Cetakan ke-11, Jakarta: PT Raja Grafindo Persada, 2009.

Soekanto, Soerjono, Penelitian Hukum Normatif, Jakarta: PT. Raja Grafindo Persada, 2006.

Soimin, Shoedharyo, Hukum Orang dan Keluarga Perspektif Hukum Perdata/BW Hukum Islam dan Hukum Adat, Jakarta: Sinar Grafika, 2004.

Sudarsono, Hukum Perkawinan Nasional, Jakarta: Rineka Cipta, 2005. , Pokok-pokok Hukum Islam, Jakarta: PT. Rineka Cipta, 2001.

Supriyadi, Dedi, Fiqh Munakahat Perbandingan dari Tekstualitas sampai Legislasi, Bandung: CV Pustaka Setia, 2011.

Susilo, Budi, Prosedur Gugatan Cerai, Yogyakarta: Pustaka Yustisia, 2007.

Sutantio, Retnomulan dan Iskandar Oeripkartawinata, Hukum Acara Perdata Dalam

Teori dan Praktek, Bandung: Mandar Maju, 2009.

Sutiyoso, Bambang, Metode Penemuan Hukum, Yogyakarta: UII Press, 2012. , Penyelesaian Sengketa Bisnis, Yogyakarta: Citra Media Hukum, Suloh Jurnal Program Studi Magister Hukum, Vol. 8, No. 1, April 2020, pp. 67 - 69 
2006.

Sy., Musthofa, Kepaniteraan Peradilan Agama, Jakarta: Kencana, 2005.

Syahrani, Riduan, Perkawinan dan Perceraian Bagi Pegawai Negeri Sipil, Jakarta: Media Sarana Press, 1986.

Syaifudin, Muhammad, Hukum Perceraian, Palembang: Sinar Grafika, 2012.

Syarifuddin, Muhammad, Sri Turatmiyah dan Annalisa Yahanan, Hukum Perceraian, Jakarta: Sinar Grafika, 2014.

Tresna, R., Peradilan di Indonesia dari Abad ke Abad, Jakarta, 1957.

Trijono, Rachmat, dkk., Hak Menguasai Negara Di Bidang Pertanahan, Jakarta: Badan Pembinaan Hukum Nasional, 2015.

Tutik, Titik Triwulan, Pengantar Hukum Perdata di Indonesia, Jakarta: Prestasi Pustaka Publiser, 2006.

Wadong, Maulana Hassan, Advokasi Dan Hukum Perlindungan Anak, Jakarta: PT.Grasindo, 2000.

Wardah, Sri dan Bambang Sutiyoso, Hukum Acara Perdata Dan Perkembangannya di Indonesia, Cetakan Pertama, Yogyakarta: Gama Media, 2007.

Yunas, Didi Nazmi, Konsepsi Negara Hukum, Padang: Angkasa Raya, 1992.

Zed, Mestika, Metode Penelitian Kepustakaan, Jakarta: Yayasan Obor Indonesia, 2007.

\section{B. Jurnal, Makalah, dan Sumber Ilmiah Lainnya}

Dani, Umar, Memahami Kedudukan Pengadilan Tata Usaha Negara di Indonesia: Sistem Unity of Jurisdiction atau Duality of Jurisdiction? Sebuah Studi Tentang Struktur dan Karakteristiknya, Jurnal Hukum dan Peradilan, Volume 7 Nomor 3, November 2018.

Kantaprawira, Rusadi, Hukum dan Kekuasaan, Makalah, Yogyakarta: Universitas Islam Indonesia, 1998.

M. Hadjon, Philipus, Tentang Wewenang, Jurnal YURIDIKA, No.5\&6 Tahun XII, September-Desember, 1997.

Manan, Bagir, Prospek Peradilan Tata Usaha Negara di Indonesia, disampaikan dalam Rapat KoordinasiNasional MA-RI Dengan Jajaran Peradilan Tata Usaha Negara Se-Indonesia Tahun 2008, di Hotel Panghegar Bandung, 14-16 Januari 2008.

Nasution, Bahder Johan, Sejarah Perkembangan Kekuasaan Kehakiman Di Indonesia, Jurnal Inovatif, Volume VII Nomor III September 2014, hlm. 14-16, https://media.neliti.com/media/publications/43226-ID-sejarah-perkembangankekuasaan-kehakiman-di-indonesia.pdf.

P., Endah, Sejarah Peradilan Agama Mahkamah Agung Republik Indonesia Direktorat Jenderal badan Peradilan Agama, https://badilag.mahkamahagung.go.id/sejarah/profil-ditjen-badilag-1/sejarahditjen-badilag.

Suloh Jurnal Program Studi Magister Hukum, Vol. 8, No. 1, April 2020, pp. 68 - 69 
Pane, Erina, Eksistensi Mahkamah Syar'iyah Sebagai Perwujudan Kekuasaan Kehakiman, Jurnal $A L-' A D A L A H$ Vol. XIII, No. 1, Juni 2016, hlm. 41. https://media.neliti.com/media/publications/56429-ID-eksistensi-mahkamahsyariyah-sebagai-per.pdf.

Pramesti, Tri Jata Ayu, Perbedaan Peradilan Dengan Pengadilan, https://www.hukumonline.com/klinik/detail/ulasan/lt548d38322cdf2/perbedaa n-peradilan-dengan-pengadilan/.

Tjandra, W. Riawan, Perbandingan Sistem Peradilan Tata Usaha Negara dan Conseil d'etat sebagai Institusi Pengawas Tindakan Hukum Tata Usaha Negara, Jurnal Hukum IUS QUIA IUSTUM NO. 3 VOL. 20 JULI 2013, hlm. 424, https://media.neliti.com/media/publications/84722-none-366328b1.pdf.

\section{Peraturan Perundang-undangan:}

Undang-Undang Dasar Negara Republik Indonesia Tahun 1945 Setelah Amandemen Undang-Undang Nomor 1 Tahun 1974 tentang Perkawinan

Undang-undang Nomor 7 Tahun 1989 tentang Peradilan Agama yang telah diubah dengan Undang-Undnag Noor 3 Tahun 2006 dan Undang-Undnag Nomor 50 Tahun 2009.

Undang-Undang Nomor 5 Tahun 1986 yang telah diubah dengan Undang-Undang Nomor 9 Tahun 2004 dan Undang-Undang Nomor 51 Tahun 2009

Peraturan Pemerintah Nomor 10 Tahun 1983 tentang Izin Perkawinan dan Perceraian Bagi Pegawai Negeri Sipil yang telah diubah dengan Peraturan Pemerintah Nomor 45 Tahun 1990.

Peraturan Pemerintah Nomor 9 Tahun 1975 tentang Pelaksanaaan Undang-Undang Nomor 1 Tahun 1974 tentang Perkawinan.

Instruksi Presiden Nomor 1 Tahun 1991 tentang Kompilasi Hukum Islam

Yurisprudensi Mahkamah Agung Nomor 11K/AG/2001

\section{Sumber Lain}

Tim Penyusun Kamus Pusat Pembinaan dan Pengembangan Bahasa, Kamus Besar Bahasa Indonesia, Jakarta: Balai Pustaka.

Pustaka Pelajar, Kumpulan Undang-Undang Peradilan Terbaru, Yogyakarta: Pustaka Pelajar, 2005.

Suloh Jurnal Program Studi Magister Hukum, Vol. 8, No. 1, April 2020, pp. 69 - 69 